\title{
A three-year investigation of the performance of spring-calving dairy cows grazing ryegrass-based pastures of high or low endophyte toxin status in Northland
}

\author{
R.G. KEOGH ${ }^{1}$ and M.B. BLACKWELL ${ }^{2}$ \\ ${ }^{2}$ Dexcel, Hamilton \\ ${ }^{1}$ AgResearch, Private Bag 11008, Palmerston North \\ email:reg.keogh@agresearch.co.nz
}

\begin{abstract}
On-farm milk production and ancillary information was monitored for spring-calving cows grazing high (HT) and low toxin (LT) pastures in Northland over three seasons from spring 1997 to autumn 2000. Two groups of 16 second-calving Holstein-Friesian cows, balanced for calving date and production worth, grazed HT or LT ryegrass pastures from October 1997 to May 1998. Milk production was monitored for 10 consecutive days each month culminating with a herd test. The LT group out-produced the HT group for each measurement period from December, and over the whole season, produced $20 \%$ more milk solids. The HT group had significantly higher serum lysergol levels and correspondingly lower prolactin levels than the LT group. As pasture quality was similar it was suggested that the differences in milk production were most likely due to differences in intake.
\end{abstract}

At the start of the $1998-1999$ season $25 \%$ of the farm was in low endophyte ryegrass or in ryegrass with the AR1 endophyte. The farm and herd were split so that milk production from HT and LT farmlets could be monitored. Milk from each group was collected into separate tanks and all cows were 'herd-tested' 4-weekly. Despite twothirds of the LT farmlet being conserved for silage, which resulted in a severe feed shortage that necessitated supplements being fed-out on this farmlet from January, the LT group out-produced the HT group by $5 \%$ per cow and by $10 \%$ per hectare for the season from October to late May.

In the 1999-2000 season, the farm and herd split was $29 \%$ LT and $71 \%$ HT. The objective was changed to one of maximising production from each system and this required changes in management. The LT system was managed to encourage clover-dominance from mid-spring and this was achieved by lengthening the rotation out to 6 weeks and then reducing it back to 3.5 weeks by leaving higher residuals and conserving $<10 \%$ of the surplus. In contrast, a fast rotation (2.5 to 3 week) was used for the HT system and surplus feed was conserved. The LT pastures contained considerably more clover than the HT pastures. The only differences in pasture quality were in the November-December period when protein and soluble carbohydrate levels were higher in LT than HT pastures. The LT system out-produced the HT system by $8 \%$ per cow and by $12 \%$ per hectare.

Issues surrounding the establishment and maintenance of LT pastures are discussed.

Keywords: dairy cows, endophyte toxins, milk production, Northland, ryegrass

\section{Introduction}

An association between seasonal milk production and endophyte toxin levels in perennial ryegrass was recorded in a small on-farm trial in spring-calving dairy cows in Northland in 1997-98 (Keogh et al. 1999; Blackwell \& Keogh 1999). On the basis of a $20 \%$ production advantage to the low toxin (LT) group, the owners increased the pastures sown in LT ryegrasses to $25 \%$ of the dairy farm area. This allowed the dairy farm and herd to be split into two farmlets $[25 \% \mathrm{LT}$ and $75 \%$ high toxin (HT)] managed separately from October 1998 to April 2000.

The dairy farm of Paul and Ruth Shepherds' at Te Hana has a Holstein-Friesian herd that is in a longterm Sire Proving Scheme.

The aims for years 2 and 3 were:

1. To test if the production differences observed in $1997 / 98$ were repeatable in other seasons.

2. To assess whether these effects could be captured within a dairy farm system, as well as on a per-cow basis.

3. In 1999-2000, to manage each farmlet separately to achieve the maximum production within each system.

The outcomes of these assessments in terms of milk production and ancillary information are reported in this paper. 


\section{Methods}

1997-1998

\section{Pastures}

The HT pastures used were high endophyte ryegrass cultivars sown with red and white clovers, from 1991 to 1993 . The LT pastures were: a) 1.3 ha of 2-year-old, low-endophyte ( $<20 \%$ infection rate) pasture; b) 1.4 ha sown in autumn 1997 with AR1 ryegrass (Keogh et al. 1999), red and white clovers. A further 2.3 ha of this seeds mix was sown in spring 1997; and c) endophytefree tall fescue-based pastures that were grazed, if required, outside of the 10-day monitoring periods.

\section{Animals and management}

Two groups of 16 3-year-old, second-calving cows, balanced for production worth and calving date, grazed the respective HT and LT sets of pastures from October 1997 until mid-April 1998. The aim was to ensure that similar pasture allowances were presented to each group throughout the trial period. Very hot, dry conditions in February resulted in low pasture growth rates and a maize-based supplement was fed to both groups to ensure that the two groups were maintained on their respective pastures.

\section{Measurements}

Milk meters were installed so that daily production records could be kept for 10-day periods each month for all cows in the trial. A monthly herd test followed each monitoring period. Daily maximum and minimum temperatures and relative humidities were recorded from January to April. Body temperatures were recorded and blood samples taken the day before each herd test. Serum prolactins and lysergol levels were determined.

Botanical composition, pasture quality, endophyte status, ergovaline and lolitrem B concentrations were determined on pasture samples (Keogh et al. 1999; Blackwell \& Keogh 1999).

\section{8-1999}

As the LT farmlet comprised mainly new low endophyte $(<10 \%$ of seeds infected) pastures compared to older pastures in the HT farmlet, the main effort was placed on monitoring milk production.

\section{Herd composition}

In October 1998, the herd was split on a stratified random basis, except for the 2-year-old heifers which, as sire proving animals, remained with the larger herd on HT pastures. The HT and LT herds were balanced for age, production worth, and liveweight in October 1998 and apart from cull cows and the entry of second-calvers in October 1999, the LT group was kept on LT pastures continuously until April 2000. At the start of the 1999/2000 season each farmlet was stocked at $1270 \mathrm{~kg}$ liveweight/ha.

\section{Milk production}

From October 1998, milk from each herd was collected separately so that volume, composition, and solids produced were able to be computed daily. Per-cow production was also computed from 4-weekly herd tests and enabled production of the two-year-old heifers to be separately assessed so that direct comparisons between the LT and HT herds could be made.

\section{9-2000}

With most pastures having been grazed for at least 1 year, the aims were redefined to attempt to maximise production from each farmlet. Management objectives for the HT farmlet were to achieve a 3-week or faster rotation, and to conserve surpluses as is the usual practice. Management on the LT farmlet was aimed at maximising the potential for red and white clover production from late spring by lengthening the rotation out to 5 weeks, by not conserving surpluses, by leaving greater residues after grazing, and then returning to a 3-week rotation.

\section{Pasture measurements}

Five pairs of LT and HT pastures were regularly sampled pre- and post-grazing to determine herbage mass and pasture growth by mowing $3 \times 5 \mathrm{~m}$ strips to $5 \mathrm{~cm}$ above the soil surface. Pre-grazing samples were taken along transects at grazing height for assessment of nutritional value and botanical composition, and 50 ryegrass tillers per pasture were taken to determine endophyte toxin levels. Toxin levels were separately determined for leaf blade and sheath portions of ryegrass tillers.

\section{Cow monitoring}

Cow condition was assessed, and a cow-weighing programme was implemented, in the 1999/2000 season. Blood samples were collected from a subgroup of weighed cows and monitored for GGT and prolactin levels.

\section{Results}

\section{A Milk production}

Production per cow was static over the 1997-2000 period, but total production increased in line with increased stocking rate (Table 1). On average, twothirds of seasonal production was achieved in what was effectively the first half of lactation. 


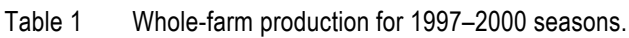

\begin{tabular}{lcccccccc}
\hline Season & kg MS & $\begin{array}{c}\text { kg MS } \\
/ \text { Eff }\end{array}$ & $\begin{array}{c}\text { Max. cows } \\
\text { milked }\end{array}$ & $\begin{array}{c}\text { Max. } \\
\text { cows/Eff } \\
\text { ha }\end{array}$ & $\begin{array}{c}\text { kg MS } \\
\text { /cow }\end{array}$ & $\begin{array}{c}\text { kg MS } \\
\text { to 31 } \\
\text { Dec. }\end{array}$ & $\begin{array}{c}\text { Calving } \\
\text { date }\end{array}$ & $\begin{array}{c}\text { Drying } \\
\text { off date }\end{array}$ \\
\hline $97 / 98$ & 56862 & 652 & 203 & 2.3 & 280 & 447 & $1-$ Aug & 12-May \\
$98 / 99$ & 59373 & 681 & 211 & 2.4 & 281 & 419 & $1-$ Aug & 25-May \\
$99 / 00$ & 65627 & 753 & 230 & 2.6 & 285 & 512 & 1-Aug & 1-May \\
\hline
\end{tabular}

1 Milk solids

${ }^{2}$ Effective hectares

In 1997/1998, results for two groups of 16 secondcalving cows maintained continuously on HT and LT pastures from October to mid-April showed an advantage from $25 \%$ to $>50 \%$ to the LT group from December until the trial was terminated (Figure 1).

In 1998/1999, the first season of split farm and herd, a production advantage to the LT farmlet began in late November (Figure 2). This advantage was not able to be sustained into January as pasture production was severely curtailed after two-thirds of this farmlet was cut for silage and hay. This conserved feed was then fed back to the LT herd over late-summer to early-autumn. The production advantage recurred during March and was maintained to drying off in late May. Seasonal production was $49 \mathrm{~kg} \mathrm{MS} / \mathrm{ha}$ higher than for the HT farmlet.

In 1999/2000, a production advantage to the LT farmlet began in early November and continued through to early February. Seasonal production was $58 \mathrm{~kg} \mathrm{MS} / \mathrm{ha}$ higher than for the HT farmlet (Figure 3).

\section{B Animal monitoring}

There were no differences in mean body temperatures recorded in 1997-1998, or in liveweights of the HT and LT groups during 1999-2000 (Figure 4). Serum lysergol and prolactin levels were higher and lower respectively in the HT than in the LT groups in 19971998 (Keogh et al. 1999).

\section{Pasture results 1999/2000}

Growth rates

Growth rates determined from cage cuts were similar for the two farmlets for the year May 1999 to April 2000 except during NovemberDecember when rates were higher on the HT farmlet (Figure 5).

\section{Clover content}

Clovers contributed more to LT than to HT pastures in 1999-2000 (Figure 6).

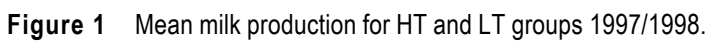

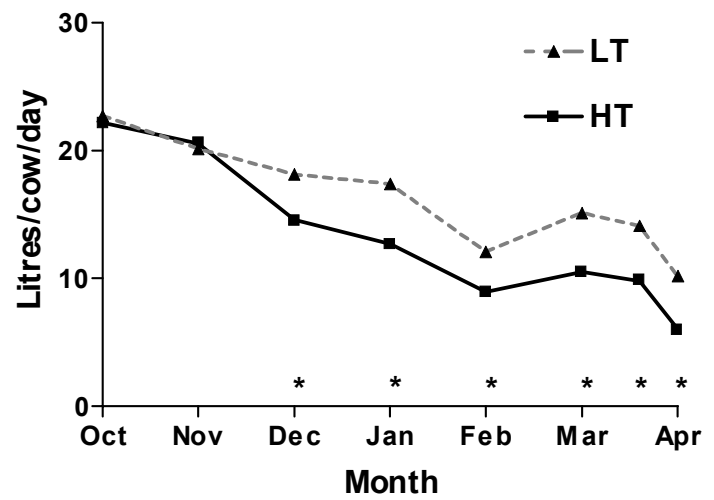

* means significantly different at $\mathrm{P}<0.05$

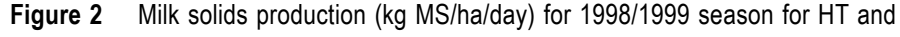
LTherds $\llbracket$ excluding heifers.

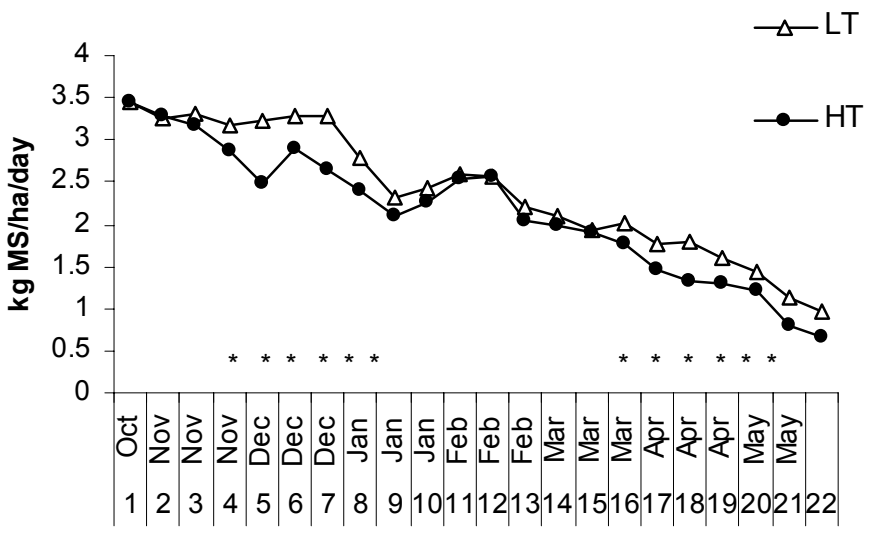

successive 10-day period means from 20th October 1998 to 25th May 1999

* means significantly different at $\mathrm{P}<0.05$

Toxin content

Ergovaline and lolitrem B yields/ha were higher for HT than for LT pastures (Figure 7).

Pasture quality

Protein and soluble carbohydrate levels were higher for LT than for HT pastures only in the November- 


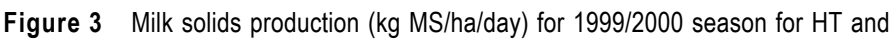
LThherds`excluding $₫$ heifers.

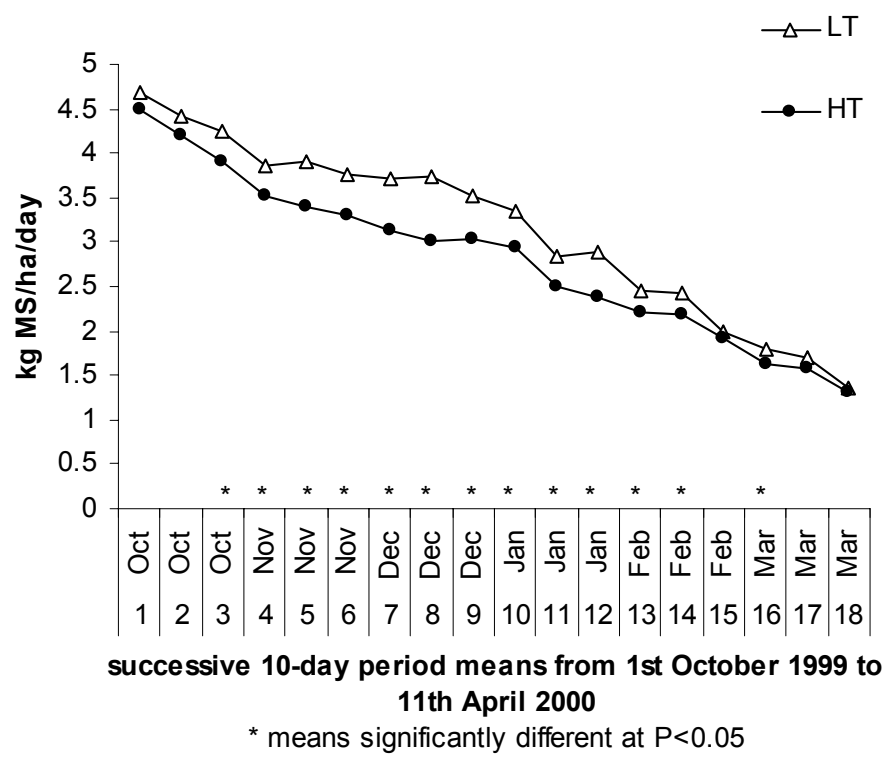

December period (Figure 8). Organic matter digestibility (OMD) and metabolisable energy (ME) values were not different between LT and HT pastures.

\section{Discussion}

The milk production advantage that occurred to the LT over the HT group in the 1997/1998 season has now been demonstrated subsequently on a splitfarm, split-herd situation. The treatment comparison in 1998-1999 with the farm and herd split was confounded by two main factors. First, a high proportion of the LT farmlet comprised newlyestablished pastures; second, a disproportionate number (two-thirds) of these pastures were taken out of the grazing rotation for conservation. This disadvantaged the LT herd when recovery of these pastures from cutting was seriously affected by the early onset of dry, summer conditions that necessi-

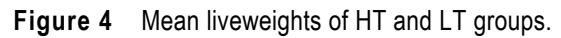

1999-2000

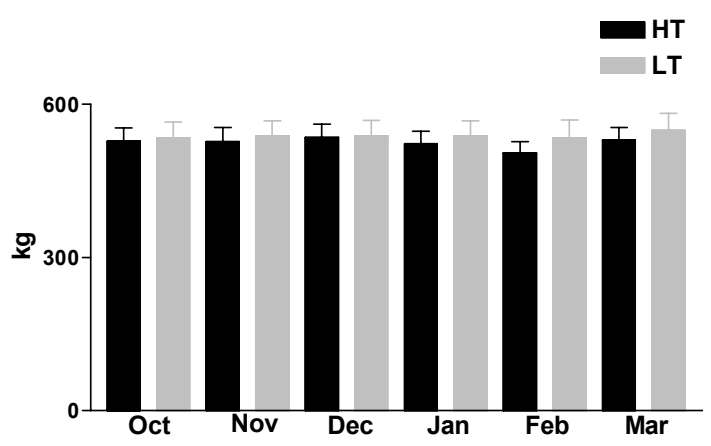

Error bars represent $95 \%$ confidence interval

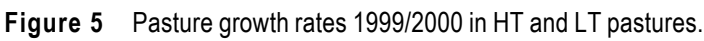

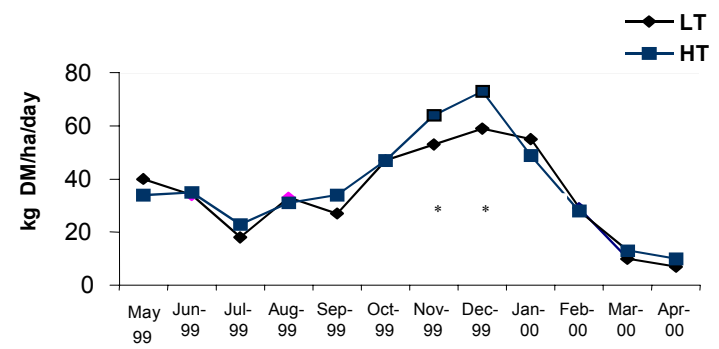

* means significantly different at $\mathrm{P}<0.05$ tated the immediate feeding out of these supplements. The result was that large management differences occurred between the treatments with respect to harvesting, and the feeding out of surplus feed as silage.

Despite this, the LT farmlet out-produced the HT farmlet by $49 \mathrm{~kg} \mathrm{MS} / \mathrm{ha}$. Most of the production difference occurred in November and December, and in late autumn. No production differences occurred when the LT herd was being fed supplements.

The objectives were changed for the 1999/2000 season to try to optimise the potential of each system

Figure $\llbracket 6 \quad$ Legume $\llbracket$ content $\llbracket$ (\% $\%$ derived $\square$ from $\square$ back-transformed means $\square$ after $\square$ analysis $) \square$ of $\square \mathrm{HT} \square$ and $\square \mathrm{LT} \square$ pastures $\square$ during 1999-2000.IPercentageicontentitransformedlaslarcsine square $[$ root]of $[$ [forlanalysis.

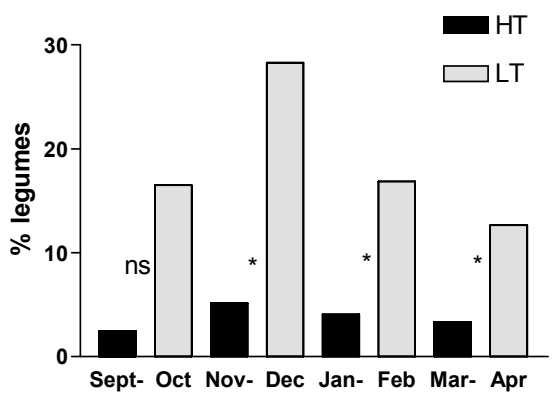

ns not significant * means significantly different at $\mathrm{P}<0.05$ 


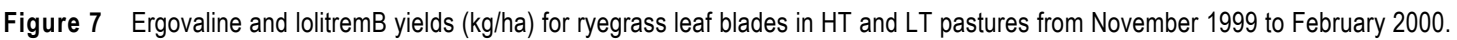

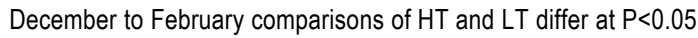

A

Ergovaline

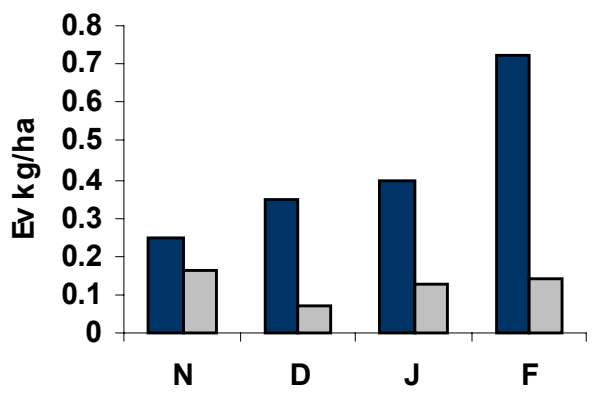

B

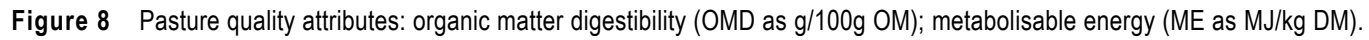

Shepherd 1999-2000

Pasture protein

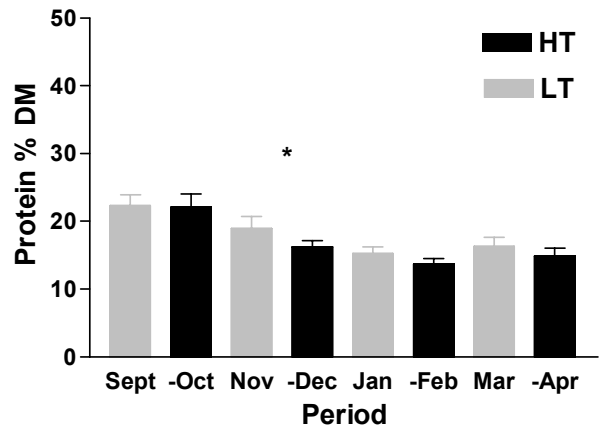

* differences are significant at $\mathrm{P}<0.05$
Lolitrem B

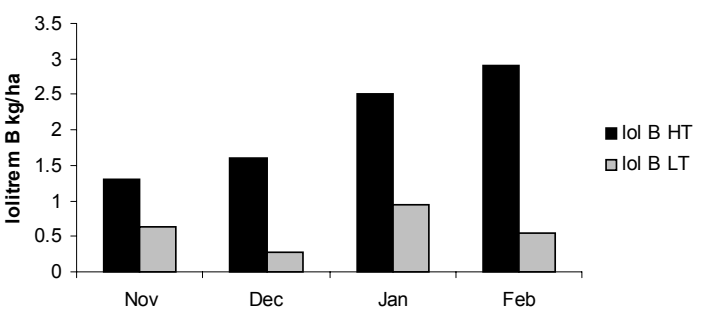

OMD

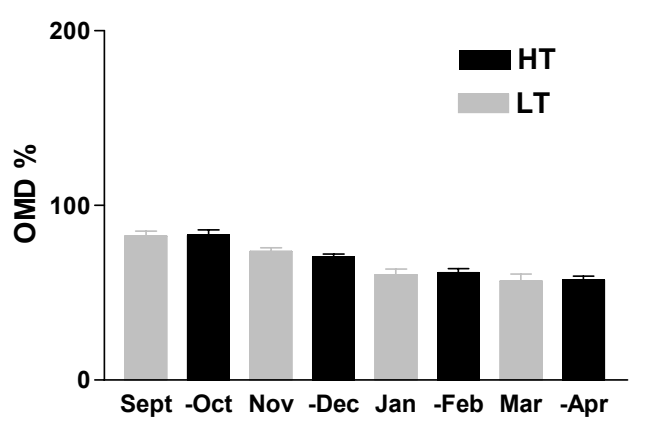

Soluble carbohydrates

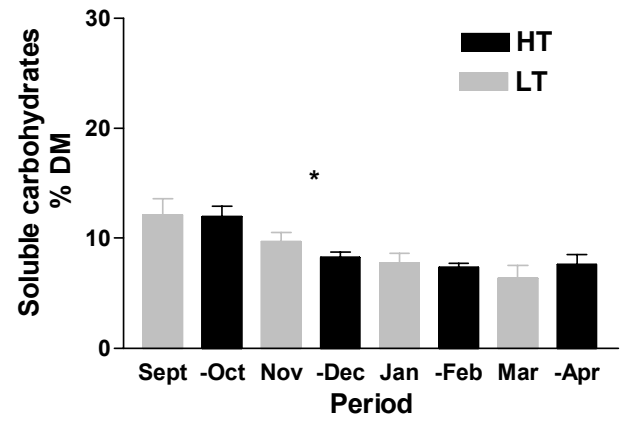

ME

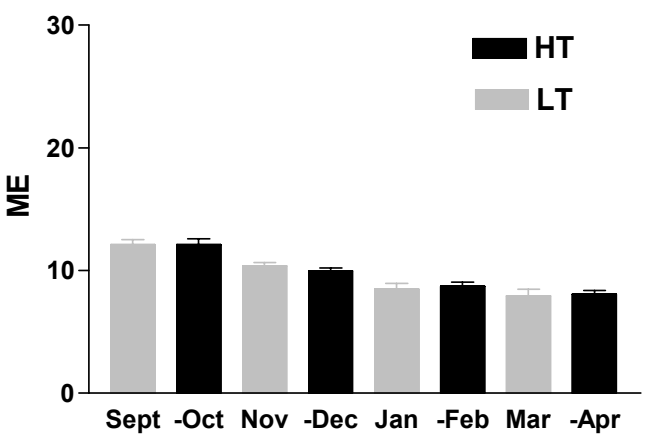

Error bars represent 95\% confidence interval 
for milk production. This led to the adoption of very different managements, particularly in conservation policy and grazing management, for each farmlet. It was considered that the main advantage of the LT system for achieving milk production was in the potential for LT pastures to become clover-dominant in the late-spring-summer period. This was achieved through implementing a longer rotation in OctoberNovember, allowing higher pasture mass to accumulate, and to then start a more lax grazing regime. The higher legume content of the LT pastures (Figure 6) from November to the end of pasture monitoring shows that this objective for the LT farmlet was achieved.

The objective for the HT farmlet was to maximise milk production by reducing the production of endophyte toxins in ryegrass through adoption of a rapid rotation to ensure that cows were grazing regrowth that was no older than 3 weeks. The rationale for this approach was that endophyte, and the neurotoxin, lolitrem $\mathrm{B}$, accumulate in ryegrass leaves as they mature and start to senesce (Keogh et al. 1996). Surplus feed was conserved as silage made as early as practicable.

The 1999/2000 season in Northland was notable for favourable growth conditions in early spring, followed by a typical dry summer with persistent very dry conditions into late autumn. The milk production comparison was terminated at the end of March by which time the LT farmlet had out-produced the HT farmlet by $58 \mathrm{~kg} \mathrm{MS} / \mathrm{ha}$ and by $25 \mathrm{~kg} \mathrm{MS} / \mathrm{cow}$.

No differences in liveweight of cows was noted during the milking season, but it was observed that the LT group put on more condition during late-autumn and winter (Blackwell unpublished). A similar improvement in condition occurred in autumn 1998 (Blackwell \& Keogh 1999) with LT cows recovering condition more rapidly following autumn rains than HT cows did. Liveweight responses obtained with ewes grazing LT and HT ryegrass pastures during autumn and winter (Watson 2000) followed a similar pattern. Such responses were most likely due to higher intakes on LT pastures, as differences in pasture quality did not exist over this period in Watson's study.

The advantages of LT pastures can only be sustained as long as their low toxin status is maintained. This depends on keeping the rate of ingress of ryegrass with wild-type endophytes (WT) to a low level, a task that requires a good understanding of the processes by which re-infestation occurs. Observations made during this investigation have highlighted one such process, which is the reseeding that occurs from WT ryegrass in LT pastures. Seed-heads on endophyte-free (EF) ryegrass are grazed by cows, but those on WT ryegrass are not, thus ensuring seed-set occurs only on WT ryegrass. Removal of seed heads before seed-set is one strategy that would slow the rate of ingress of WT ryegrass.

The main grasses available for inclusion in LT pastures are EF and low endophyte $(<10 \%)$ ryegrass cultivars, ryegrass cultivars that contain the AR1 endophyte (don't produce ergovaline or lolitrem B), and tall fescue cultivars. Extra production of $50 \mathrm{~kg}$ $\mathrm{MS} /$ hectare for LT pastures for two seasons will generally recoup renovation costs, especially if pasture renewal follows cropping. A further advantage to renewal after cropping is that the risk of ryegrass ingression from viable WT ryegrass seed is reduced.

If the consistent production advantages obtained from LT over HT pastures can be captured on a larger scale, they could be a major part of the strategy for attainment of industry objectives (Bodeker \& Anderson 2001).

\section{ACKNOWLEDGEMENTS}

Paul and Ruth Shepherd for their co-operation and commitment throughout; Brian Tapper and Liz Davies, Chemistry Group, AgResearch, for ergovaline and lolitrem B analyses; the financial support and interest of the Whangarei-Maungatapere Veterinary Trust, the Hine Rangi Trust, and the Ellett Trust are gratefully acknowledged.

\section{REFERENCES}

Blackwell, M.B.; Keogh, R.G. 1999. Endophyte toxins and performance of spring-calving dairy cows in Northland. Ryegrass endophyte: an essential New Zealand symbiosis. Grassland Research and Practice Series 7: 45-50.

Bodeker, P.C.W.; Anderson, F.A. 2001. 4\% productivity - What does it mean for farmers? Proceedings Ruakura Farmers' Conference 53: 48-52.

Keogh, R.G.; Blackwell, M.B.; Shepherd, P. 1999. Performance of dairy cows grazing pastures with or without ergovaline and lolitrem B in Northland. Proceedings of the New Zealand Society of Animal Production 59: 254-257.

Keogh, R.G.; Tapper, B.A.; and Fletcher, R.H. 1996. Distributions of the fungal endophyte, Acremonium lolii, and of the alkaloids lolitrem B and peramine, within perennial ryegrass. New Zealand Journal of Agricultural Research 39: 121-127.

Watson, R.H. 2000. Endophytic perennial ryegrass and reproductive performance of the ewe. $\mathrm{PhD}$ thesis, Massey University. 